\title{
KOMBINASI KOTORAN TERNAK (AYAM, KAMBING, DAN KUDA) SEBAGAI MEDIA KULTUR PERTUMBUHAN Daphnia sp.
}

\section{COMBINATION OF ANIMAL WASTE (CHICKEN, GOAT, AND HORSE) FOR CULTURE MEDIA Daphnia sp.}

\author{
Fadilah Suci ${ }^{1 \star}$, Sri Murwani ${ }^{1}$, Tugiyono ${ }^{1}$, Endang Linirin Widiastuti ${ }^{1}$ \\ 1Jurusan Biologi FMIPA, Universitas Lampung \\ Jl. Prof. Dr. Sumantri Brojonegoro No. 1 Bandar Lampung 35145 \\ *e-mail : fadilahsuci18@yahoo.co.id
}

\begin{abstract}
ABSTRAK
Penelitian ini bertujuan untuk mengetahui peningkatan populasi dan laju pertumbuhan Daphnia sp. pada beberapa media yang menggunakan kotoran ayam, kotoran kuda, kotoran kambing, dan kombinasi kotoran tersebut serta mengetahui media kultur terbaik dalam menunjang peningkatan populasi Daphnia sp. Disamping itu penelitian ini juga bertujuan untuk mengetahui korelasi antara kepadatan fitoplankton media dengan kepadatan Daphnia sp. Penelitian ini menggunakan Rancangan Acak Lengkap (RAL) yang terdiri dari enam perlakuan yang diulang 3 kali, yaitu P1: kotoran ayam 100\%, P2: kotoran kambing 100\%, P3: kotoran kuda 100\%, P4: kotoran ayam 50\% + kotoran kambing $25 \%$ + kotoran kuda $25 \%$, P5: kotoran kambing $50 \%$ + kotoran ayam $25 \%$ + kotoran kuda 25\%, P6: kotoran kuda 50\% + kotoran ayam 25\% + kotoran kambing 25\%. Parameter yang diamati adalah kepadatan populasi Daphnia sp., laju pertumbuhan populasi spesifik, pertumbuhan fitoplankton sebagai pakan Daphnia sp., uji proksimat (kotoran ayam, kambing, kuda, dan kombinasinya), dan kualitas air. Hasil penelitian menunjukkan bahwa kombinasi kotoran ternak (ayam, kambing, dan kuda) memberikan pengaruh yang nyata terhadap kepadatan populasi Daphnia $\mathrm{sp} .(\mathrm{p}<0,05)$ serta berpengaruh nyata juga terhadap laju pertumbuhan populasi spesifik Daphnia sp. $(p<0,05)$. Perlakuan P4 kombinasi kotoran ayam 50\% + kotoran kambing $25 \%$ + kotoran kuda $25 \%$ menghasilkan kepadatan puncak populasi Daphnia sp. terbaik sebesar 1.840 individu/L dan laju pertumbuhan populasi spesifik sebesar $56,51 \% /$ hari.
\end{abstract}

Kata kunci: Daphnia sp., kotoran ternak, laju pertumbuhan spesifik

\begin{abstract}
This aims of the study was to determine the increase in population and the growth rate of Daphnia sp. in media consisted of manures : chicken, horse, and goat, as well as their combinations, and also to identify the best quality of media which support the Daphnia sp. population growth. The study was also to determined corelation between density of phytoplankton on the media and Daphnia sp. This study used a completely randomized design (CRD), which consisted of six treatments with each three replications, namely $\mathrm{P} 1: 100 \%$ chicken manure, P2: $100 \%$ goat manure, P3: $100 \%$ horse manure, P4: $50 \%$ chicken manure $+25 \%$ goat manure $+25 \%$ horse manure, P5: $50 \%$ goat manure $+25 \%$ chicken manure $+25 \%$ horse manure, P6: $50 \%$ horse manure $+25 \%$ chicken manure $+25 \%$ goat manure . The observed parameters were the population density of Daphnia sp. , a specific population growth rate, the growth of phytoplankton, proximate values (chicken manure, goats, horses, and combinations thereof), and water quality. The results showed that the combination of animal manure (chicken, goats, and horses) provided significant effect on population density of Daphnia sp. $(p<0.05)$ and a significantly effect also on the specific growth rate of Daphnia sp. population $(p<0.05)$. The treatment P4 which was combination of chicken manure $50 \%+25 \%$ goat manure $+25 \%$ horse manure yielded the highest density populations of Daphnia sp. of 1.840 ind /l and the specific population growth rate was $56,51 \%$ / day.
\end{abstract}

Keywords: Daphnia sp. , manure, specific growth rate

\section{PENDAHULUAN}

Ketersediaan nutrisi dari pakan alami sangat berpengaruh terhadap

pertumbuhan benih ikan. Menurut
Djarijah, (1955) umumnya pakan alami untuk ikan merupakan jenis renik yang hidup di dalam air seperti fitoplankton dan zooplankton. Hal ini karena pakan alami 
seperti fitoplankton dan zooplankton memiliki beberapa kelebihan seperti ukurannya yang sesuai dengan bukaan mulut ikan dan gerakan menarik yang ditimbulkan pakan alami tersebut dapat merangsang larva ikan untuk memangsanya (Casmuji, 2002).

Daphnia sp. merupakan salah satu jenis zooplankton yang dimanfaatkan sebagai pakan alami karena mengandung protein yang cukup tinggi yaitu sekitar 42,65 \% dan sangat dibutuhkan untuk pertumbuhan ikan (Djarijah, 1995 dan Mufidah dkk., 2009 ). Di samping itu Daphnia sp. merupakan salah satu zooplankton yang mudah dikultur dengan media yang baik untuk pertumbuhan yaitu pada kualitas air yang sesuai dengan pertumbuhannya dan tersedianya sumber makanan yang cukup untuk tumbuh dan perkembangannya (Hadiwigeno, 1984).

Menurut (Casmuji, 2002) pupuk organik dapat menumbuhkan fitoplankton yang berfungsi sebagai pakan Daphnia sp. dalam media kultur. Kotoran ternak sebagai sumber pupuk organik dapat dimanfaatkan sebagai sumber nutrisi bagi pertumbuhan fitoplankton.

Kotoran hewan ternak pada umumnya mengandung nitrogen, fosfor, dan kalium. Nitrogen dan fosfor berperan penting dalam menumbuhkan fitoplankton sebagai pakan Daphnia sp. serta kalium berfungsi untuk menambah daya tahan tubuh
Daphnia sp. (Casmuji, 2002). Namun demikian, pemanfaatan kotoran ternak yang dikombinasikan belum diketahui peranannya dalam pengulturan Daphnia sp. Untuk itu perlu dilakukan penelitian kultur Daphnia sp. yang menggunakan kotoran ternak ayam, kambing, dan kuda untuk mencari komposisi kotoran ternak yang dikombinasikan sebagai media kulturnya yang dapat meningkatkan pertumbuhan optimal dari Daphnia sp.

\section{BAHAN DAN METODE PENELITIAN}

Penelitian ini dilaksanakan pada bulan Desember 2014 di Laboratorium Bio Molekuler II Jurusan Biologi Fakultas Matematika dan IImu Pengetahuan Alam Universitas Lampung. Alat yang digunakan selama penelitian adalah toples kaca dengan tinggi $25 \mathrm{~cm}$ dan berdiameter $14 \mathrm{~cm}$ sebanyak 36 unit yang dilengkapi aerator untuk memasok oksigen terlarut agar kualitas lingkungan hidup Daphnia sp. terjaga. Alat-alat penunjang yang digunakan yaitu kain kasa sebagai penutup bagian atas toples kaca, timbangan dan alat sampling seperti gelas bekker, cawan petri, dan pipet tetes, alat untuk mengukur kualitas air yang terdiri dari termometer, DO meter, dan $\mathrm{pH}$ test kit, kemudian alat untuk menghitung fitoplankton yang terdiri dari haemocytometer dan mikroskop. Bahan yang digunakan selama penelitian adalah Daphnia sp. sebanyak 720 ekor, kotoran ayam, kotoran kambing, dan kotoran kuda. 
Penelitian ini menggunakan Rancangan Acak Lengkap (RAL), yang terdiri dari 6 perlakuan dengan 3 kali ulangan yaitu:

$\mathrm{P} 1=$ kotoran ayam 100\% (2,4 g/L) sebagai pembanding (Sulasingkin, 2003)

$\mathrm{P} 2=$ kotoran kambing $100 \%(2,4 \mathrm{~g} / \mathrm{L})$

P3 = kotoran kuda 100\% (2,4 g/L)

$\mathrm{P} 4=$ kotoran ayam 50\% (1,2 g/L $)+$ kotoran kambing 25\% $(0,6 \mathrm{~g} / \mathrm{L})+$ kotoran kuda 25\% (0,6 g/L)

$\mathrm{P} 5=$ kotoran kambing $50 \%(1,2 \mathrm{~g} / \mathrm{L})+$ kotoran ayam $25 \%(0,6 \mathrm{~g} / \mathrm{L})+$ kotoran kuda $25 \%(0,6 \mathrm{~g} / \mathrm{L})$

P6 = kotoran kuda 50\% (1,2 g/L) + kotoran ayam 25\% $(0,6 \mathrm{~g} / \mathrm{L})+$ kotoran kambing 25\% (0,6 g/L).

Semua toples yang akan digunakan sebagai wadah pemeliharaan dicuci dengan bersih dan didiamkan hingga benar-benar kering. Selanjutnya toples diisi dengan air sawah yang dicampur dengan air tawar dengan perbandingan 1:3 sebanyak 2 liter lalu diaerasi, kemudian ditebar Daphnia sp. dengan kepadatan 20 ekor/liter. Daphnia sp. didapatkan dari penjual pakan ikan hias di Jalan Hayam Wuruk No. 1 Tanjung Karang, Bandar Lampung.

Kotoran ternak yang digunakan (kotoran ayam, kambing, dan kuda) sebelumnya dikeringkan terlebih dahulu selama seminggu. Setelah dilakukan penebaran Daphnia sp., 2 jam kemudian media kultur diberi kotoran ayam, kambing, dan kuda, serta kombinasi kotoran dengan dosis sesuai perlakuan yaitu P1: kotoran ayam $100 \%$, P2: kotoran kambing 100\%, P3: kotoran kuda 100\%, P4: kotoran ayam $50 \%+$ kotoran kambing $25 \%+$ kotoran kuda 25\%, P5: kotoran kambing 50\% + kotoran ayam $25 \%$ + kotoran kuda $25 \%$, P6: kotoran kuda $50 \%$ + kotoran ayam $25 \%$ + kotoran kambing 25\%. Pemberian kotoran ternak dilakukan setiap 6 hari sekali.

Pemeliharaan Daphnia sp. dilakukan selama 12 hari. Sedangkan penghitungan jumlah Daphnia sp. dilakukan dua hari sekali dalam waktu 12 hari. Sampel air diambil sebanyak $100 \mathrm{ml}$ dengan menggunakan gelas bekker dituangkan sedikit demi sedikit kedalam cawan petri kemudian dihitung.

Laju pertumbuhan populasi spesifik Daphnia sp. dihitung dengan menggunakan rumus modifikasi Becker (1994), yaitu :

$$
\mu=\frac{\operatorname{LnNt}-\operatorname{Ln} \mathrm{No}}{\mathrm{t}} \times 100 \%
$$

Keterangan :

No : kepadatan awal populasi (Individu/L)

$\mathrm{Nt}$ : kepadatan akhir populasi fase eksponensial (Individu/L)

t : waktu (hari) dari No ke Nt

$\mu \quad$ : laju pertumbuhan populasi spesifik (\%/hari). 
Pada penelitian ini juga dilakukan penghitungan kepadatan fitoplankton pada air media kultur Daphnia sp. yang bertujuan untuk melihat korelasi antara pertumbuhan fitoplankton dengan pertumbuhan populasi Daphnia sp. Kepadatan fitoplankton dihitung dengan cara mengambil sampel air pada media kultur lalu diteteskan di haemocytometer kemudian ditutup dengan cover glass lalu dihitung. Kepadatan fitoplankton dihitung dengan menggunakan rumus menurut Isnansetyo dan Kurniastuti (1995) yaitu :

Jumlah sel $=\mathrm{n} \times 25 \times 10^{4}=\ldots \mathrm{sel} / \mathrm{ml}$

\section{Keterangan:}

$\mathrm{n} \quad$ : rata-rata jumlah sel (dari 5 kotak)

25 : jumlah chamber

$10^{4}$ : volume kepadatan chamber

Pengukuran kualitas air suhu, oksigen terlarut, $\mathrm{pH}$, dan amonia dilakukan pada hari ke 0 , hari ke 6 , dan hari ke 12 .

Data kepadatan puncak dan laju pertumbuhan populasi spesifik Daphnia sp. dianalisis dengan menggunakan sidik ragam (ANOVA), jika terdapat hasil yang berbeda nyata antar perlakuan dilanjutkan dengan uji BNT pada taraf $5 \%$.

\section{HASIL DAN PEMBAHASAN}

Hasil

1. Kepadatan Populasi Daphnia sp.

Kepadatan populasi Daphnia sp. meningkat pada hari pertama hingga hari ke 8 dan terjadi penurunan populasi pada hari ke 9 hingga hari ke 12 pengulturan. Kepadatan populasi Daphnia sp. pada masing-masing perlakuan dapat dilihat pada Gambar 1.

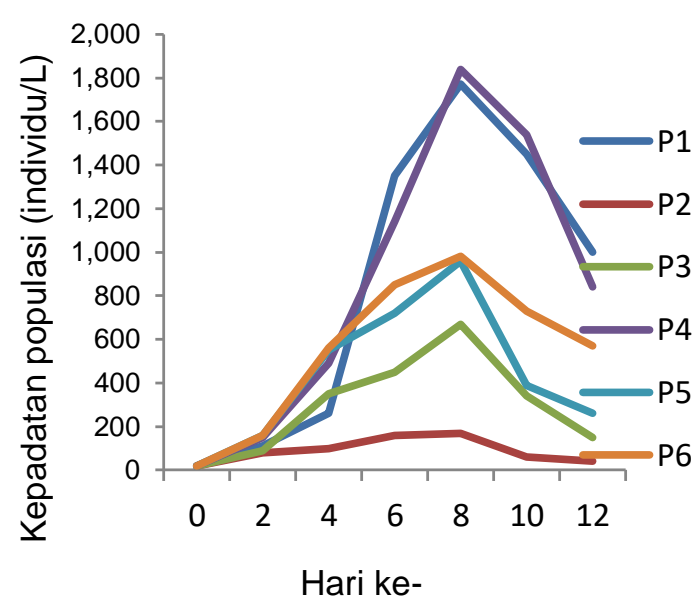

Gambar 1. Kepadatan populasi Daphnia sp.

Rata-rata kepadatan puncak Daphnia sp. dari yang terendah sampai tertinggi adalah pada media P2 yaitu 170 individu/L, P3 yaitu 670 individu/L, P5 yaitu 960 individu/L, P6 yaitu 980 individu/L, P1 yaitu 1.770 individu/L, dan P4 yaitu 1.840 individu/L. Kepadatan populasi Daphnia sp. tertinggi pada hari ke 8 terdapat pada perlakuan ke 4 yaitu pada pemberian kombinasi kotoran ayam $50 \%+$ kotoran kambing $25 \%+$ kotoran kuda $25 \%$ sebanyak 1.840 individu/L. Sedangkan kepadatan populasi terendah terdapat pada perlakuan ke 2 yaitu pada pemberian 
kotoran kambing $100 \%$ sebanyak 170 individu/L dapat dilihat pada Tabel 1.

Tabel 1. Rerata kepadatan puncak populasi Daphnia sp. hari ke 8 (individu/L)

\begin{tabular}{cc}
\hline Perlakuan & Rerata \pm SD \\
\hline P1 & $1.770 \pm 26,45 \mathrm{a}$ \\
P2 & $170 \pm 10,00 \mathrm{~d}$ \\
P3 & $670 \pm 112,69 \mathrm{c}$ \\
P4 & $1.840 \pm 52,91 \mathrm{a}$ \\
P5 & $960 \pm 52,91 \mathrm{~b}$ \\
P6 & $980 \pm 20,00 \mathrm{~b}$ \\
\hline
\end{tabular}

Keterangan: Nilai rerata pada kolom yang sama dan diikuti oleh huruf yang sama menunjukkan tidak berbeda nyata pada $\alpha 5 \%$.

Hasil uji BNT menunjukkan bahwa pada media P4 berbeda nyata dengan media P2, P3, P5, dan P6 $(p<0,05)$ terhadap kepadatan puncak populasi Daphnia sp. , tetapi tidak berbeda nyata dengan media P1. Kemudian pada media P5 tidak berbeda nyata dengan media P6.

\section{Laju Pertumbuhan Populasi Spesifik} Daphnia sp.

Hasil rerata laju pertumbuhan populasi spesifik Daphnia sp. yang tertinggi terdapat pada kombinasi kotoran ayam $50 \%+$ kotoran kambing $25 \%+$ kotoran kuda 25\% (P4) yaitu 56,51\%/hari, sedangkan laju pertumbuhan populasi spesifik Daphnia sp. terendah terdapat pada media kultur yang diberi kotoran kambing $100 \%$ (P2) yaitu 26,73\%/hari dapat dilihat pada Tabel 2.
Tabel 2. Rerata laju pertumbuhan populasi spesifik Daphnia sp. (\%/hari)

\begin{tabular}{cc}
\hline Perlakuan & Rerata (\%/hari) \pm SD \\
\hline P1 & $56,03 \pm 0,19 \mathrm{a}$ \\
P2 & $26,73 \pm 0,73 \mathrm{~d}$ \\
P3 & $43,78 \pm 2,02 \mathrm{c}$ \\
P4 & $56,51 \pm 0,35 \mathrm{a}$ \\
P5 & $48,37 \pm 0,69 \mathrm{~b}$ \\
P6 & $48,64 \pm 0,25 \mathrm{~b}$ \\
\hline
\end{tabular}

Keterangan: Nilai rerata pada kolom yang sama dan diikuti oleh huruf yang sama menunjukkan tidak berbeda nyata pada $\alpha 5 \%$.

Hasil uji BNT menunjukkan bahwa pada media P4 berbeda nyata dengan media P2, P3, P5, dan P6 $(p<0,05)$ terhadap laju pertumbuhan populasi spesifik Daphnia sp., tetapi tidak berbeda nyata dengan media P1. Kemudian pada media P5 tidak berbeda nyata dengan media P6.

\section{Korelasi Kepadatan Daphnia sp. dengan Kepadatan Fitoplankton}

Korelasi kepadatan Daphnia sp. dengan kepadatan fitoplankton pada berbagai media kotoran ternak dan korelasi kepadatan Daphnia sp. dengan kepadatan fitoplankton pada berbagai media kultur Daphnia sp dapat dilihat pada Gambar 2.

Pada Gambar 2 korelasi antara kepadatan Daphnia sp. dengan pertumbuhan fitoplankton pada berbagai media kultur Daphnia sp. memiliki nilai $r=0,40$ dengan persamaan $y=221,7 \mathrm{x}+84720$. Sedangkan korelasi antara kepadatan Daphnia sp. dengan pertumbuhan fitoplankton pada berbagai media kotoran 
ternak adalah $r=0,87$ dengan persamaan

menunjukkan bahwa terdapat hubungan $y=1609 x+500.000+06$. Hal ini positif antara kedua korelasi tersebut.

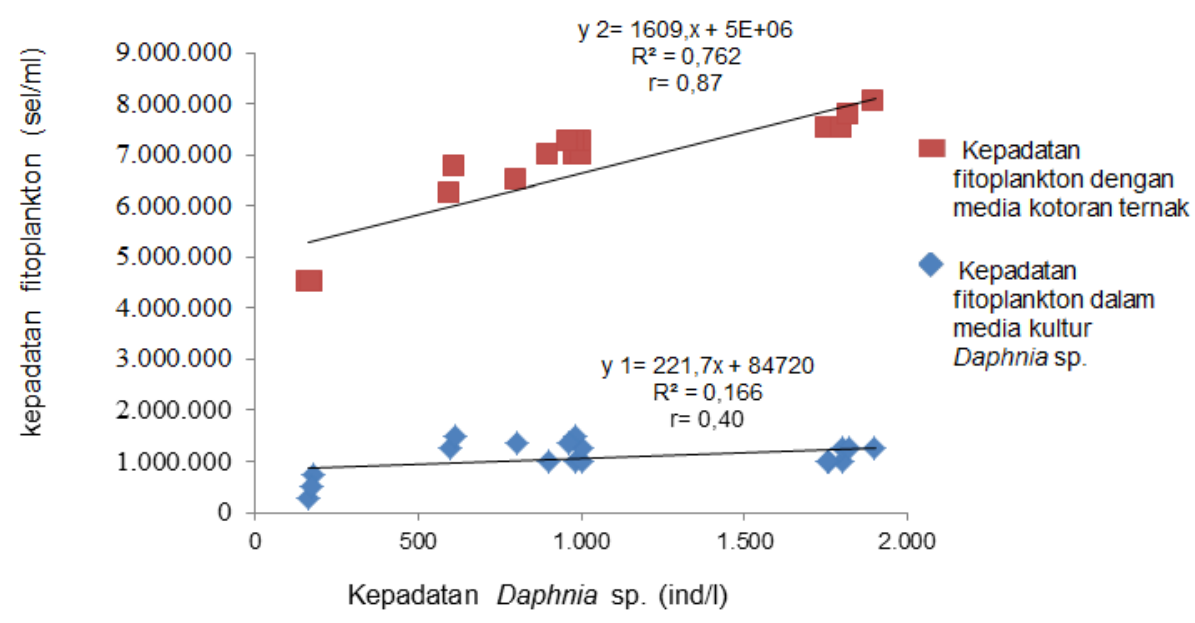

Gambar 2. Korelasi kepadatan Daphnia sp. dengan kepadatan fitoplankton dalam media kultur dan korelasi kepadatan Daphnia sp. dengan kepadatan fitoplankton pada berbagai media kotoran ternak

\section{Analisis Proksimat}

Data hasil uji proksimat kotoran ayam, kambing, kuda, serta kombinasinya disajikan pada Tabel 3.

Tabel 3. Analisis proksimat kotoran ayam, kambing, kuda, serta kombinasi kotoran

\begin{tabular}{|c|l|c|c|c|}
\hline No & \multicolumn{1}{|c|}{ Nama Sampel } & Protein & \multicolumn{1}{c|}{ Lemak } & Karbohidrat \\
\cline { 3 - 4 } & & 2,21 & 1,81 & 29,29 \\
\hline 1 & Kotoran Ayam 100\% & 2,25 & 3,53 & 25,78 \\
\hline 2 & Kotoran Kambing 100\% & 3,32 & 4,26 & 26,25 \\
\hline 3 & Kotoran Kuda 100\% & 3,00 & 2,37 & 37,55 \\
\hline 4 & $\begin{array}{l}\text { Kotoran Ayam 50\% + Kotoran Kambing 25\% } \\
\text { + Kotoran Kuda 25\% }\end{array}$ & & \\
\hline
\end{tabular}

Sumber : Laboratorium Teknologi Hasil Pertanian Politeknik Negeri Lampung (2015)

\section{Kualitas Air}

Hasil pengukuran kualitas air yang berupa suhu, DO, dan $\mathrm{pH}$ pada media kultur masih dalam kisaran layak untuk pertumbuhan Daphnia sp. Sedangkan pada kandungan amonia terjadi peningkatan hingga hari ke12. Hasil pengukuran parameter kualitas air media pemeliharaan selama penelitian disajikan pada Tabel 4. 
Tabel 4. Hasil pengukuran kualitas air selama penelitian

\begin{tabular}{|c|c|c|c|c|c|c|c|c|c|c|}
\hline \multirow{4}{*}{ Perlakuan } & \multicolumn{10}{|c|}{ Parameter } \\
\hline & \multicolumn{3}{|c|}{ Suhu $\left({ }^{\circ} \mathrm{C}\right)$} & \multirow{2}{*}{\multicolumn{2}{|c|}{ DO (ppm) }} & \multicolumn{3}{|c|}{$\mathrm{pH}$} & \multicolumn{2}{|c|}{ Amonia (mg/l) } \\
\hline & \multicolumn{8}{|c|}{ Hari ke- } & & \\
\hline & 1 & 6 & 12 & 1 & 6 & 1 & 6 & 12 & 1 & 12 \\
\hline P1 & 28 & 27,5 & 27 & $\begin{array}{l}3,5 \\
3,8\end{array}$ & 3,6 & 7 & $7-8$ & $7-8$ & $\begin{array}{l}0,08 \\
0,67\end{array}$ & 0,12 \\
\hline $\mathrm{P} 2$ & 28 & 27,4 & 27 & $\begin{array}{l}3,5 \\
3,8\end{array}$ & 3,7 & 7 & $7-8$ & $7-8$ & $\begin{array}{l}0,08 \\
0,41\end{array}$ & 0,20 \\
\hline P3 & 28 & 27,5 & 27 & $\begin{array}{l}3,5 \\
3,7\end{array}$ & 3,6 & 7 & $7-8$ & $7-8$ & $\begin{array}{l}0,08 \\
0,64\end{array}$ & 0,17 \\
\hline P4 & 28 & 27,5 & 27 & $\begin{array}{l}3,5 \\
3,8\end{array}$ & 3,6 & 7 & $7-8$ & $7-8$ & $\begin{array}{l}0,08 \\
0,36\end{array}$ & 0,09 \\
\hline P5 & 28 & 27,6 & 27 & $\begin{array}{l}3,5 \\
3,8\end{array}$ & 3,6 & 7 & $7-8$ & $7-8$ & $\begin{array}{l}0,08 \\
0,33\end{array}$ & 0,09 \\
\hline P6 & 28 & 27,3 & 27 & $\begin{array}{l}3,5 \\
3,8\end{array}$ & 3,7 & 7 & 7-8 & $7-8$ & $\begin{array}{l}0,08 \\
0,12\end{array}$ & 0,084 \\
\hline $\begin{array}{l}\text { Standar } \\
\text { kelayakan }\end{array}$ & & $22-32$ & & & $>3,5$ & & 7,1-8, & & & $<0,2$ \\
\hline Referensi & & $\begin{array}{c}\text { sumary } \\
1988)\end{array}$ & & & $\begin{array}{l}\text { umaryanto } \\
1988)\end{array}$ & & $\begin{array}{r}\text { Mokogi } \\
2003 \\
\end{array}$ & & & $\begin{array}{l}\text { lbare and } \\
\text { ert, 1996) }\end{array}$ \\
\hline
\end{tabular}

\section{Pembahasan}

Kepadatan puncak populasi Daphnia sp. pada media yang diberi kotoran ayam $50 \%+$ kambing $25 \%$ + kuda 25\% (P4) menunjukkan hasil rerata kepadatan puncak populasi tertinggi yaitu 1.840 individu/L. Tingginya kepadatan populasi Daphnia sp. pada media yang diberi kotoran ayam 50\% + kambing 25\% + kuda 25\% (P4) karena pada media kultur memiliki kandungan protein yang cukup tinggi yaitu 3,00\% dan karbohidrat 37,55\% (Tabel 3). Suryanti dkk. (1997) menyatakan bahwa protein dapat mempengaruhi tinggi rendahnya pertumbuhan, sedangkan karbohidrat berfungsi sebagai sumber energi (Nuraini dan Nuraini, 2008). Kondisi media dengan nutrisi yang baik atau cukup menurut Zahidah (2012) dapat membuat Daphnia sp. muda akan tumbuh dan berganti kulit sehingga menjadi individu dewasa dan bereproduksi yang akhirnya dapat meningkatkan populasi Daphnia sp.

Pada media kultur yang diberi kotoran kambing $100 \%$ (P2) menunjukkan hasil rerata kepadatan puncak populasi terendah yaitu 170 individu/L (Tabel 1). Rendahnya kepadatan populasi Daphnia sp. pada media P2 karena pada media memiliki kandungan protein dan karbohidrat yang lebih rendah dibandingkan dengan P4 yaitu masingmasing sebesar 2,25\% dan 25,78\% (Tabel 3). Suryanti dkk. (1997) menyatakan bahwa kekurangan protein akan berpengaruh negatif terhadap konsumsi pakan yang berdampak terjadinya penurunan berat tubuh, sedangkan kekurangan karbohidrat menyebabkan kurangnya sumber energi (Nuraini dan Nuraini, 2008). 
Kepadatan populasi Daphnia sp. juga dipengaruhi oleh keberadaan fitoplankton dalam media kultur. Menurut Suwignyo (1989), pakan Daphnia sp. selain bahan organik tersuspensi dan bakteri adalah fitoplankton. Pertumbuhan populasi Daphnia sp. pada hari pertama sampai tahap puncak disebabkan oleh kandungan unsur hara yang berasal dari kotoran ternak yang terdapat dalam media kultur dimanfaatkan oleh fitoplankton untuk pertumbuhan. Pada media yang diberi kotoran ayam 50\% + kambing 25\% + kuda $25 \%$ (P4) memiliki kepadatan populasi fitoplankton yang cukup tinggi sehingga ketersediaan pakan bagi Daphnia sp. tercukupi.

Pemakaian kotoran ternak sebagai bahan media kultur diduga dapat merangsang pertumbuhan mikroorganisme dan fitoplankton yang berfungsi sebagai pakan Daphnia sp. Hal ini berdasarkan pendapat Setyamidjaja (1986), bahwa kotoran ternak mengandung semua unsur hara yang dapat dimanfaatkan fitoplankton sebagai nutrisi bagi pertumbuhannya. Sedangkan pada media yang diberi kotoran kambing 100\% (P2) memiliki kepadatan puncak populasi fitoplankton yang cukup rendah. Rendahnya populasi fitoplankton pada P2 karena media yang diberikan adalah kotoran kambing 100\% sehingga kandungan unsur hara dalam media kultur kurang maksimal bagi pertumbuhan fitoplankton. Kemudian rendahnya kepadatan populasi Daphnia sp. pada media P2 disebabkan oleh kandungan amonia yang tinggi yaitu mencapai 0,41mg/l (Tabel 4). Menurut Delbare dan Dhert (1996) kadar amonia yang tinggi dapat menurunkan tingkat reproduksi Daphnia sp.

Penurunan populasi Daphnia sp. terjadi pada hari ke 9 (Gambar 1), diduga karena bahan organik dalam media kultur semakin berkurang dan kandungan amonia yang meningkat (Tabel 4). Dugaan ini berdasarkan pernyataan Firdaus (2004), bahwa penyebab terjadinya penurunan populasi Daphnia sp. setelah puncak populasi karena semakin berkurangnya bahan organik terlarut. Pernyataan tersebut didukung oleh Mubarak (2009), bahwa kandungan amonia berasal dari dekomposisi bahan organik, sisa hasil metabolisme yaitu feses dan urine, serta pemupukan pakan yang tidak dimanfaatkan oleh Daphnia sp. yang memiliki sifat racun dalam media pemeliharaan.

Laju pertumbuhan populasi spesifik Daphnia sp. pada media dengan kombinasi kotoran ayam 50\% + kambing $25 \%$ + kuda $25 \%$ (P4) menunjukkan laju pertumbuhan populasi tertinggi, sedangkan laju pertumbuhan populasi Daphnia sp. pada media yang diberi kotoran kambing 100\% (P2) menunjukkan hasil rerata laju pertumbuhan populasi terendah (Tabel 2). Kondisi ini diduga berhubungan dengan kandungan nutrisi 
yang ada dalam media kultur tersebut. Dugaan ini sesuai pendapat Hermawan dkk. (2001), bahwa laju pertumbuhan populasi zooplankton dipengaruhi oleh media nutrien, suhu, dan kadar oksigen dalam air.

Tingginya laju pertumbuhan populasi spesifik Daphnia sp. pada media P4, karena memiliki kandungan protein dan karbohidrat yang cukup tinggi yaitu masing-masing sebesar $3,00 \%$ dan $37,55 \%$, sehingga dapat mencukupi kebutuhan nutrisi Daphnia sp. Sedangkan pada pemberian kotoran kambing $100 \%$ (P2) memiliki kandungan protein dan karbohidrat yang lebih rendah dibandingkan dengan media P4 yaitu masing-masing sebesar 2,25\% dan $25,78 \%$ (Tabel 3) sehingga kurang maksimal untuk kebutuhan nutrisi Daphnia sp.

Kemudian pada media P4 memiliki kepadatan puncak populasi fitoplankton yang cukup tinggi sedangkan pada media P2 memiliki kepadatan puncak fitoplankton yang lebih rendah dibandingkan dengan media P4. Semakin tinggi populasi fitoplankton yang ada dalam media kultur maka ketersediaan pakan bagi Daphnia sp. juga meningkat, sehingga dapat mencukupi kebutuhan energi untuk pertumbuhan Daphnia sp. yang ditandai dengan peningkatan populasi. Peningkatan kepadatan fitoplankton karena unsur hara yang terkandung dalam kotoran ternak dapat memenuhi kebutuhan nutrisi fitoplankton untuk pertumbuhannya. Pertumbuhan fitoplankton dapat mendukung pertumbuhan Daphnia sp. oleh salah satu faktor yaitu konsentrasi pakan, jika faktor tersebut terpenuhi maka pertumbuhan Daphnia sp. berlangsung baik dan menghasilkan populasi yang tinggi (Ninuk, 2011).

Suhu selama penelitian berkisar antara 27-28 ${ }^{\circ} \mathrm{C}$ dan masih berada dalam kisaran optimum pertumbuhan Daphnia sp. (Tabel 4). Menurut Kusumaryanto (1988), suhu optimum pertumbuhan Daphnia sp. berkisar antara $22-32{ }^{\circ} \mathrm{C}$. Oksigen terlarut dalam media kultur secara keseluruhan berkisar antara 3,5-3,8 ppm dan masih berada dalam kisaran optimum pertumbuhan Daphnia sp. (Tabel 4). Menurut Kusumaryanto (1988), oksigen terlarut yang baik untuk pertumbuhan Daphnia sp. yaitu $>3,5 \mathrm{ppm}$. Secara keseluruhan $\mathrm{pH}$ pada penelitian ini berkisar antara 7-8 dan masih berada dalam kisaran optimum pertumbuhan Daphnia sp. (Tabel 4). Menurut Mokoginta (2003) $\mathrm{pH}$ netral dan relatif basa pada kisaran 7,1-8,0 adalah $\mathrm{pH}$ yang baik untuk pertumbuhan Daphnia sp. Nilai amonia selama penelitian berkisar antara 0,08-0,67 mg/l. Pada air media kultur terjadi peningkatan amonia hingga hari ke12 yang mengakibatkan terjadinya penurunan populasi Daphnia sp. (Tabel 4). Delbare dan Dhert (1996) menyatakan 
kadar amonia yang tinggi dapat menurunkan tingkat reproduksi Daphnia sp. Kadar amonia yang aman bagi kultur Daphnia sp. adalah di bawah 0,2 mg/L.

\section{KESIMPULAN}

Berdasarkan hasil penelitian diperoleh kesimpulan yaitu penggunaan kombinasi kotoran ayam $50 \%$ + kotoran kambing $25 \%$ + kotoran kuda 25\% (P4) dalam media kultur menunjukkan kepadatan populasi tertinggi Daphnia sp. dibandingkan dengan media lain yang diuji yaitu 1.840 individu/L dengan laju pertumbuhan populasi spesifik tertinggi Daphnia sp. yaitu $56,51 \% /$ hari.

\section{DAFTAR PUSTAKA}

Becker, E. W. 1994. Microalgae

Biotechnology And Microbiology.

Cambridge University Press. Great Britain England.

Casmuji. 2002. Penggunaan Supernatan Kotoran Ayam dan Tepung Terigu Dalam Budidaya Daphnia Sp. [Skripsi]. Departemen Budidaya Perairan. Fakultas Perikanan dan Ilmu Kelautan. Institut Pertanian Bogor. Bogor.

Delbare, D and P. Dhert. 1996. Cladocerans, Nematodes and Trocophara Larvae. In Manual on Production and Use of Live Food (P. Lavens and P. Sorgelos, ens). page 283-295.

Djarijah, A.S. 1995. Pakan Alami. Kansius. Yogyakarta.

Firdaus, M. 2004. Pengaruh Beberapa Cara Budidaya Terhadap Pertumbuhan Populasi Daphnia Sp. [Skripsi]. Program Studi Budidaya Perairan Fakultas
Perikanan dan Ilmu Kelautan Institut Pertanian Bogor. 47 hlm.

Hadiwigeno, S. 1984. Kultur Makanan Alami (Daphnia sp.). Departemen Pertanian. Direktorat Jendral Perikanan, BBAT. Sukabumi.

Hermawan, A., Anindiastuti., K.A. Wahyuni dan E. Julianty. 2001. Kajian Pendahuluan Penggunaan Pakan Fermentasi Untuk Kultur Massal Cyclops sp. Buletin Budidaya Laut 13:14-23.

Isnansetyo, A dan Kurniastuti. 1995. Teknik Kultur Fitoplankton dan Zooplankton. Pakan Alami Untuk Pembenihan Organisme Laut. Kanisius. Yogyakarta.

Kusumaryanto, H. 1988. Pengaruh Jumlah Inokulasi Awal Terhadap Pertumbuhan Populasi, Bimassa dan Pembentukkan Epipium Daphnia sp. Skripsi. Fakultas Perikanan. Institut Pertanian Bogor.

Mokoginta, I. 2003. Budidaya Pakan Alami Air Tawar. Direktorat Jenderal Pendidikan Dasar dan Menengah. Departemen Pendidikan Nasional.

Mubarak, A.S. 2009. Pemberian Dolomit Pada Kultur Daphnia sp. Sistem Daily Feeding Pada Populasi Daphnia sp. dan Kestabilan Kualitas Air. Jurnal IImiah Perikanan dan Kelautan. 1(1): 6772.

Mufidah, N., B.S. Rahardja, dan W.H. Satyantini. 2009. Pengkayaan Daphnia sp. Dengan Viterna Terhadap Kelangsungan Hidup dan Pertumbuhan Larva Lele Dumbo (Clarias gariepinus). Jurnal IImiah. Universitas Airlangga. Surabaya.

Ninuk. 2011. Dinamika Fitoplankton. Indonesian Aquaculture. Tequisa Indonesia. Jakarta. 
Nuraini dan Nuraini. 2008. Pertumbuhan dan Kelulushidupan Benih Ikan Baung Yang Diberi Pakan Bokashi Dipelihara di Air Rawa. Teroka Riau. 8(3): 43-57.

Setyamidjaja, D. 1986. Pupuk dan Pemupukan. Jakarta: Simplex. hIm.122

Suryanti, Y., A. Priyadi, dan N. Suhenda. 1997. Pemberian Pakan Buatan Untuk Ikan Gabus (Chana striatus) Dalam Keramba di Kalimantan Timur. Jurnal Penelitian Perikanan Indonesia. 3(3): 35-40.
Suwignyo, S.T. 1989. Avertebrata Air. Lembaga Sumberdaya Informasi, IPB. 127 hal.

Sulasingkin, D. 2003. Pengaruh Konsentrasi Ragi yang Berbeda Terhadap Pertumbuhan Populasi Daphnia sp. Skripsi. Fakultas Perikanan dan Ilmu Kelautan Institut Pertanian Bogor.

Zahidah, 2012. Pertumbuhan Populasi Daphnia sp. Yang Diberi Pupuk Limbah Budidaya Karamba Jaring Apung (KJA) di Waduk Cirata Yang Telah Difermentasi EM4. Jurnal Akuatika. III(1): 84-94. 
Kombinasi Kotoran Ternak ... / 56 